\title{
A Comprehensive Identification of Synaptic Vesicle Proteins in Rat Brains by cRPLC/MS-MS and 2DE/MALDI-TOF-MS
}

\author{
Won-Kyu Lee, ${ }^{1,2, a}$ Hye-Jung Kim, ${ }^{1,3+a}$ Hye-Ki Min, ${ }^{+}$Un-Beom Kang, ${ }^{1}$ Cheolju Lee, ${ }^{1}$ Sang-Won Lee, ${ }^{+}$ \\ Ick Young Kim, ${ }^{2}$ Seung-Taek Lee, ${ }^{3}$ Oh-Seung Kwon, ${ }^{1}$ and Yeon Gyu Yu ${ }^{50}$ \\ ${ }^{1}$ Division of Life Sciences, Korea Institute of Science and Technologv, P.O. Box 131, Cheongryang, Seoul 130-650, Korea \\ "Laboratory of Cellutar and Holecular Biochemistry, School of Life Sciences and Biotechnologn: \\ Korea Linversin, Seoul 136-701, Korea \\ ${ }^{3}$ Department of Biochemistry, College of Science, Ionsei Linversity, Seoul 120-7t9, Korea \\ ${ }^{4}$ Deparment of Chemistry, Korea Lniwersity, Seoul 136-701, Korea \\ 'Department of Chemistry, Kookmin Lniversin, Seoul 136-702, Korea. "E-mail: venugkookminac.kr \\ Received Hav 10, 2007
}

\begin{abstract}
Proteomic analy'ses of synaptic vesicle fraction from rat brain have been performed for the better understanding of vesicle regulation and signal transmission. Two different approaches were applied to identify proteins in synaptic vesicle fraction. First. the isolated sy naptic vesicle proteins were treated with try psin and the resulting peptides were analyzed using a high-pressure capillary reversed phase liquid chromatography/tandem mass spectrometry (cRPLC/MS/MS). Alternatively proteins were separated by two-dimensional gel electrophoresis (2DE) and identified by matrix-assisted laser desorption ionization mass spectrometry (MALDI-TOF/MS). Total 18 and 52 proteins were identified from cRPLC/MS-MS and 2DE-MALDI-TOF-MS analysis. respectively. Among them only 2 proteins were identified by both methods. Of the proteins identified. $70 \%$ were soluble proteins and $30 \%$ were membrane proteins. They were categorized by their functions in vesicle trafficking and biogenesis. energy metabolism. signal transduction, transport and unknown functions. Among them. 27 proteins were not previously reported as synaptic proteins. The cellular functions of unknown proteins were estimated from the analysis of domain stnucture. expression profile and predicted interaction partners.
\end{abstract}

Key Words : Synaptic membrane proteome. Micro liquid chromatography electrospray ionization tandem mass spectrometry, Two-dimensional gel electrophoresis. Matrix-assisted laser desorption mass spectrometry, Rat brains

\section{Introduction}

Neuronal transmission in the central nervous system occurs at sy'naptic junctions. Incoming electronic signals from pre-synaptic neurons induce the release of neurotransmitters in synaptic vesicles to sy'naptic junction. and then the released neurotransmitters bind to corresponding receptors to activate the postsynaptic neurons. Synaptic vesicles are the key organelles involved in synaptic functions such as uptake. storage and stimulus-dependent release of neurotransmitters. ${ }^{1.2}$ The trafficking cycle of synaptic vesicles consists of the transport of neurotransmitters into synaptic vesicles. clustering and docking of the vesicle in front of the active zone. priming and fusion of the vesicle with the plasma membrane and recycling by endocytosis. Proteins involved in the biogenesis and transport process of synaptic vesicles have been identified from genetic as well as biochemical analy'ses. The synaptosome-associated protein receptor (SNARE) complex consisting syntaxin. ${ }^{3}$ synaptobrevin (VAMP), SNAP25. and synaptotagamins. ${ }^{5}$ is

${ }^{a}$ These authors equally contributed to this work.

Abbreviations: 2DE two-dimensional gel electrophoresis: ESI electrospray ionization: MALDI matrix-assisted laser desorption ionization: TOF time-of-flight: cRPLC capillary reversed phase liquid chromatography: QIT. quadrupole ion trap: IEF. isoelectric focusing necessary for the docking and fusion of synaptic vesicles with the plasma membrane. Cytoskeleton proteins. such as myosin-V. rab 6 and KIF3A. are involved in the transport of vesicle through the cytoplasm. "Septins are involved in the targeting of vesicles to plasma membrane. ${ }^{7.8}$ Proteins implicated in the attachment of vesicle to acceptor membranes are Rab. ${ }^{9.11}$ rabkinesin. ${ }^{11}$ rabadaptin. ${ }^{12.13}$ rabphilin. ${ }^{1+16}$ Rim. ${ }^{17}$ EEAl $^{18.19}$ and Usolp/p115. ${ }^{20.21}$ The vATPase complex. which provides energy for sequestering neurotransmitters in synaptic vesicles. is also highly expressed in the synaptic vesicle. ${ }^{22}$ In addition, transporters. receptors. and receptorassociated proteins had been identified in synapse. ${ }^{23}$

Recently. global analyses of proteins from whole organism. specific tissues or organelles have been performed due to the recent advance in high-throughput mass spectrometric techniques. ${ }^{24-26}$ Proteomes of human and mouse brain tissues have been analyzed using 2DE and MALDI-TOF-MS. and 200-450 proteins were identified. ${ }^{27-32}$ Among them, only a few proteins involved in the trafficking of synaptic vesicles or signal transduction were identified ${ }^{33}$ Analy ses of proteins in subcellular fraction from neuronal tissue. such as synaptosome or synaptic vesicles. were also carried out to identify proteins directly associated with synaptic vesicles. ${ }^{3+36 i}$ Also. synaptosomal proteins from squid optic lobe have been separated using 2DE. and highly expressed proteins were 
identified. ${ }^{37}$ Majority of these proteins were cytosolic enzymes. cytoskeletal proteins, or molecular chaperones. However, only a snall number of proteins involved in synaptic architecture and transmitter recycling were identified. In addition. 36 proteins involved in vesicle maintenance, recycling and energy metabolism were identified from 2DE and LC/MS/MS analysis of mouse brain synaptic vesicles. $^{38}$ Also 452 proteins were identified from of postsynaptic density fraction fron rat brain by LC/MS/MS analysis. ${ }^{39}$ When the proteins from these analyses were compared. uniquely identified proteins in each analysis were found, indicating that each analy sis identified only a fraction of protein in synaptic vesicle.

In this study. we have analyzed proteins associated with synaptic vesicles of rat brain in order to identify novel proteins involved in the cellular function of synaptic vesicles and components of signal transduction. To address the linitation of each MS-based proteone analysis methods. we have used 2DE-MALDI-TOF as well as CRPLC/MS/MS for the analysis of synaptic vesicle proteome. From these analyses 68 proteins were identified and categorized by their functions. and the functions of newly identified proteins were estimated. These data would provide information regarding to the molecular machinery of synaptic vesicle trafficking.

\section{Experimental Section}

Materials. Inmobilized pH gradient (IPG) strips, CHAPS, DTT were purchased from Amersham Biosciences (Uppsala. Sweden). Acrylanide and bis-acrylamide cocktail solution was obtained from Bio-Rad (Hercules. USA). Urea, thiourea. iodoacetanide and the other reagents for the polyacry lamide gel preparation were from Signa (St. Louis. USA). Reagents of silver staining were purchased from Merck (Darmstadt. Germany). The Sprague-Dawley rats $(250-300 \mathrm{~g})$ were purchased fron Santako (Seoul. Korea). The animals were sacrificed by decapitation and the whole brain was isolated. The brain samples were stored at $-80^{\circ} \mathrm{C}$ until analyzed.

Isolation of synaptic vesicles. The synaptic vesicle fraction was isolated from rat brains as described by Huttner et $\mathrm{al}^{+1)}$ Briefly. whole brain tissue $(0.5 \mathrm{~g})$ was homogenized with 10 strokes at $2.100 \mathrm{rpm}$ using a glass/Teflon homogenizer in $5 \mathrm{~mL}$ of buffer A $(4 \mathrm{mM}$ HEPES. $320 \mathrm{mM}$ sucrose. $\mathrm{pH} 7.3$ ). The membrane fraction from the brain tissue extract was further separated by ultracentrifugation in $50-800 \mathrm{mM}$ sucrose gradient for $5 \mathrm{hr}$ at $65.000 \times \mathrm{g}$. and a synaptic vesicle fraction in the $200-400 \mathrm{mM}$ sucrose region was collected. Proteins in the isolated synaptic vesicle fraction were precipitated in $20 \% \mathrm{TCA}$ in acetone containing $0.2 \% \mathrm{DTT}$, and the precipitated proteins were dissolved with $40 \mathrm{mM}$ Tris-HCl. $7 \mathrm{M}$ urea. $2 \mathrm{M}$ thiourea $4 \%$ (w/v) CHAPS. $2 \mathrm{mM}$ tributylphosphine. $1 \mathrm{mM}$ EDTA containing protease inhibitor cocktail [l tablet per $50 \mathrm{~mL}$ hỵdration solution (Roche Diagnostics. Penzberg. Germany)]. Protein concentration was determined by bicinchoninic acid method. $^{+1}$
Electron microscopy. Electron microscopic image of the isolated vesicle fraction was obtained by the same method as previously reported. ${ }^{+1}$ The isolated synaptic vesicle fraction was fixed in $120 \mathrm{mM}$ sodium cacodylate buffer $(\mathrm{pH} 7.4)$ containing $2 \%$ glutaraldelyde. The fixed synaptic vesicles were recovered by centrifugation for $\mathrm{l}$ h at $234.000 \times \mathrm{g}$. washed with $0.1 \mathrm{M}$ veronal/acetate buffer $(\mathrm{pH} 7.4)$. and post fixed in $1 \% \mathrm{OsO}_{4}$ at $4{ }^{\circ} \mathrm{C}$. Then, the samples were delyydrated in ethanol and propylene oxide. Silver sections were prepared on an Ultra-Cut 701701 microtome (Leica Microsystems. Nussloch, Germany). stained with uranyl acetate and lead citrate. and examined in a Philips 301 electron microscope (Philips Electron Optics. Eindhoven, Holland) operated at $80 \mathrm{kV}$.

Tryptic digestion of synaptic vesicle proteins. Synaptic vesicle fraction ( $30 \mu \mathrm{g}$ of proteins) was dissolved in $300 \mu \mathrm{L}$ of $100 \mathrm{mM}$ ammonium bicarbonate buffer with $6 \mathrm{M}$ urea and thermally denatured by incubation at $90^{\circ} \mathrm{C}$ for $10 \mathrm{~min}$. After the sample was cooled to room temperature. $0.6 \mu \mathrm{g}$ of sequencing grade Lys-C (Roche Diagnostics, Indianapolis, USA) was added and incubated at $37^{\circ} \mathrm{C}$ for $4 \mathrm{~h}$. The Lys-C digested sample was diluted with $600 \mu \mathrm{L}$ of $100 \mathrm{mM}$ anmonium bicarbonate buffer. and further digested with trypsin (Promega, Madison, USA) with a substrate-toenzyme ratio of $50: 1$ at $37^{\circ} \mathrm{C}$ for $15 \mathrm{~h}$. The resulting peptide mixture was applied onto a home-built micro-column (0.03" I.D. $\times 5 \mathrm{~cm}$ long. $C_{\text {Is }}$-bonded particles, $5 \mu \mathrm{m}$ particles. 300 $\AA$ pore size; Phenomenex. Torrance, USA), washed and desalted with $0.05 \%$ trifluoroacetic acid (TFA) and $0.2 \%$ acetic acid solution, and eluted with $90 \%$ acetonitrile and $0.1 \%$ TFA solution. The eluted peptide sample was completely dried and kept at $-20^{\circ} \mathrm{C}$ until required for cRPLC/ MS/MS experiments.

CRPLC/MS/MS analysis. Tryptic peptides from synaptic vesicle fractions were separated using a high-pressure capillary RPLC system that had been described in detail elsewhere. ${ }^{+2}$ Briefly. mobile phases (solvent A: $0.05 \%$ TFA and $0.2 \%$ acetic acid in water: solvent B: $90 \%$ acetonitrile. $0.1 \% \mathrm{TFA}$ in water) were delivered into a capillary column (75 $\mu \mathrm{m} \mathrm{ID} \times 360 \mu \mathrm{m}$ OD $\times 1 \mathrm{~m}$ in length) by two ISCO syrringe pumps (Lincoln. USA) at the operation pressure of 10.000 psi with an exponential gradient of $0-80 \%$ of solvent B. A quadrupole ion trap (QIT) mass spectrometer (LCQ advantage: ThermoFinnigan. San Jose. USA) equipped with a home-built nanoESI interface was used to analyze the peptides from the capillary RPLC system. To identify the eluted peptides. the QIT-MS was operated in data-dependent tanden MS mode where the four most abundant ions detected in a precursor MS scan were dynamically selected for subsequent MS/MS experiments. simultaneously incorporating dynamic exclusion option to prevent reacquisition of MS/MS spectra of the same peptides. The MS and MS/ MS data from QIT-MS experiments were analyzed using the SEQUEST program (Thermofinnigan. San Jose. USA) against a database. which was constructed by combining the IPI rat database (ftp://ftp.ebi.ac.uk/pub/databases/LPL/current) and a common contaninant database (http $/ /$ www.ncbi.nil 
gov). Database search was performed by using $m / 7$. tolerance of $3 \mathrm{Da}$ for precursor ions, and $1 \mathrm{Da}$ for fragment ions. The search results were subsequently evaluated by leptideProphet ${ }^{1.3}$ and peptides having probability score of higher than 0.5 were exported to a home-built software. ${ }^{1+1}$ where the peptide II) were further matched to proteins. Proteins having 3 or more different peptide sequences were considered as being correctly identified. l'roteins identified by one or two peptides were further analyzed by manual inspection of the corresponding MS MS spectra to Ininimize false positive identification.

Electrophoresis. 2DE was performed by the same methods as previously reported." ${ }^{15}$ About 1 mig proteins of the solubilized synaptic vesicle fraction were mixed with $2 \%$ (viv) isoelectric focusing gel buffer ( $\mathrm{pl} 3-10$ ), and then applied on an immobilized linear gradient strip (pl 3-10; Amersham Biosciences, Uppsala, Sweden). Isoelectric focusing was performed at $150 \mathrm{~V}$ for $\mathrm{l} \mathrm{h}$, at $500 \mathrm{~V}$ for 30 $\mathrm{min}$, at $1,000 \mathrm{~V}$ for $30 \mathrm{~min}$, and then kept constant at $8000 \mathrm{~V}$ for $10 \mathrm{~h}$ at $20^{\circ} \mathrm{C}$. For the second dimension electrophoresis, the IJ'G strips were incubated in equilibration buffer (1.5 $\mathrm{mM}$ Tris-HCl, $6 \mathrm{M}$ urea. $2 \%$ SDS, $30 \%$ glycerol, $2 \%$ D'"l; $\mathrm{pH} \mathrm{8.8)} \mathrm{for} 15 \mathrm{~min}$, and then incubated for $15 \mathrm{~min}$ in the equilibration buffer containing $2.5 \%$ iodoacetamide. The equilibrated $J P G$ strips were transferred to the second dimension SDS-13AGE of $10 \%$ gels. Electrophoresis was carried out at $10^{\circ} \mathrm{C}$ using a Hoeffer TM SE 600 system (Amersham Biosciences, Uppsala, Sweden). The proteins in 2DE gels were visualized by silver staining method as described previously. ${ }^{16}$ One of the five gels was chosen as the master gel, and used for the automatic matching of spots in other 2DE gels.

MALDI-TOF/MS and database search. The gel slices containing the stained protein spot were washed three times with $25 \mathrm{mM}$ ammonium bicarbonate and $50 \%$ acetonitrile solution for $1 \mathrm{~h}$. dried, and proteins in gels were digested with $12.5 \mu \mathrm{g} / \mathrm{ml}$. secjuencing grade trypsin (Promega, Madison, USA) in $25 \mathrm{mM}$ ammonium bicarbonate for overnight at $37^{\circ} \mathrm{C}$. The peptides from the gel were extracted with $60 \%$ acetonitrile solution containing $0.1 \%$ trifluoroacetic acid. After evaporation of the solvent. peptides were dissolved in $0.05 \%$ trifluoroacetic acid. $5 \%$ acetonitrile solution. One $\mu \mathrm{L}$ of the peptide mixture was mixed with the same volume of the matrix solution $(5 \mathrm{mg} / \mathrm{mL} \alpha$-cyano-4hydroxy-cinnamic acid solution in $50 \%$ acetonitrile containing $0.1 \%$ trifluoroacetic acid), and the mass values of peptides were determined by MALDI-1OH/MS (Voyager DE-PRO, Applied Biosystems, Foster City, U.S.A.) mass spectrometer. The peptide masses were compared with the theoretical peptide masses of all available proteins from Rattus norvegicus and Mus musculus. Monoisotopic masses were used with a mass tolerance of $50 \mathrm{ppm}$.

Database analysis of unknown function proteins. The function of proteins, which were not listed in gene ontology database (http:/wwwebi.ac.ukego/), was further analyzed using PSORIII (http//psort.nibb.ac.jp/ form2.html) database for the cellular localization, PROSI'te (http://www. expasy.org/prosite) and CDD (http:/www.ncbi.nlm.nih.gov/ entrez query.fegi? db=cdd) databases for the identification of structural domain, STRING database (http://string.embl.de/) for the identification of interacting proteins. Also, potential orthologs of the unknown proteins were analyzed by the prediction of protein-protein interactions using NANO_PID database (Nanormics, Inc.). Since the protein-protein interaction databases including NANO_PID did not reach saturation level, the prediction of potential orthologs based on the best match resulted in substantial limitations. ${ }^{\text {t? }}$ Indeed, orthology can be one-to-many or many-to-many relationship..$^{18}$ In this study, all matches with 5 -values lower than $10^{10}$ were considered as potential orthologs.

\section{Results}

Purification of synaptic vesicle and proteome analysis. The synaptic vesicles were purified from the homogenate of rat brain tissue by differential centrifugation and ultracentrifugation in sucrose gradient. About $1.2 \mathrm{mg}$ of synaptic vesicle proteins was obtained from $13.2 \mathrm{~g}$ of brain tissue. and the yield of synaptic vesicle was comparable to the reported value. ${ }^{40}$ The electron microphotograph of the purified synaptic vesicles shows a near homogeneous population of vesicle structure within the range of $40-70 \mathrm{~nm}$ diameter (Fig. IA, $\times 16,500$; Fig. IB, $\times 65,000$ ), which is consistent with the reported size of synaptic vesicle. ${ }^{11)}$ Subcellular

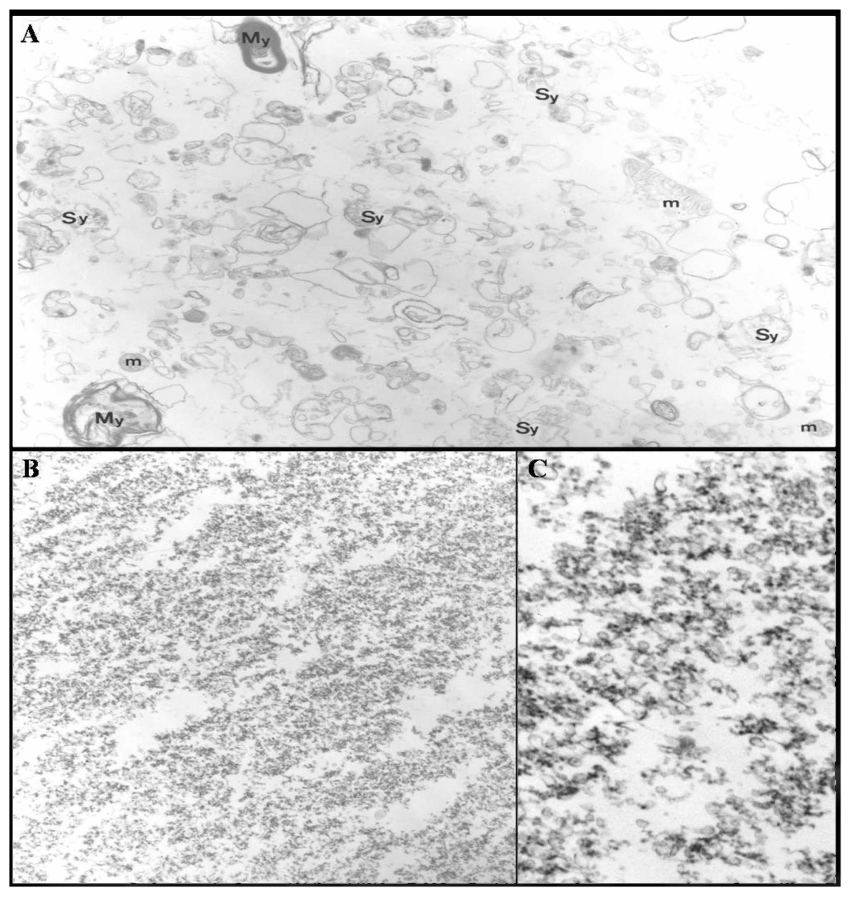

Figure 1. 'lhe electron micrograph of synaptic vesicles. Synaptic vesicles from the 200-400 m $\mathrm{M}$ sucrose region of gradient fractions were collected at $65.000 \times \mathrm{g}$ and the membrane pellet was analyzed. The image, shown at $60.000 \times$. displays a homogenous population of intact synaptic vesicles. Subcellular particles from the crude synaptosomal pellet. $\times 16,500(\mathrm{~A})$. Ilighly purilied synaptic vesicle fraction $(\mathrm{SCV}) \times 16.500(\mathrm{~B})$ and $\times 65.000(\mathrm{C})$. SW. synaptosomes; $H \cdot$, myelin sheath; $m$, mitochondria 


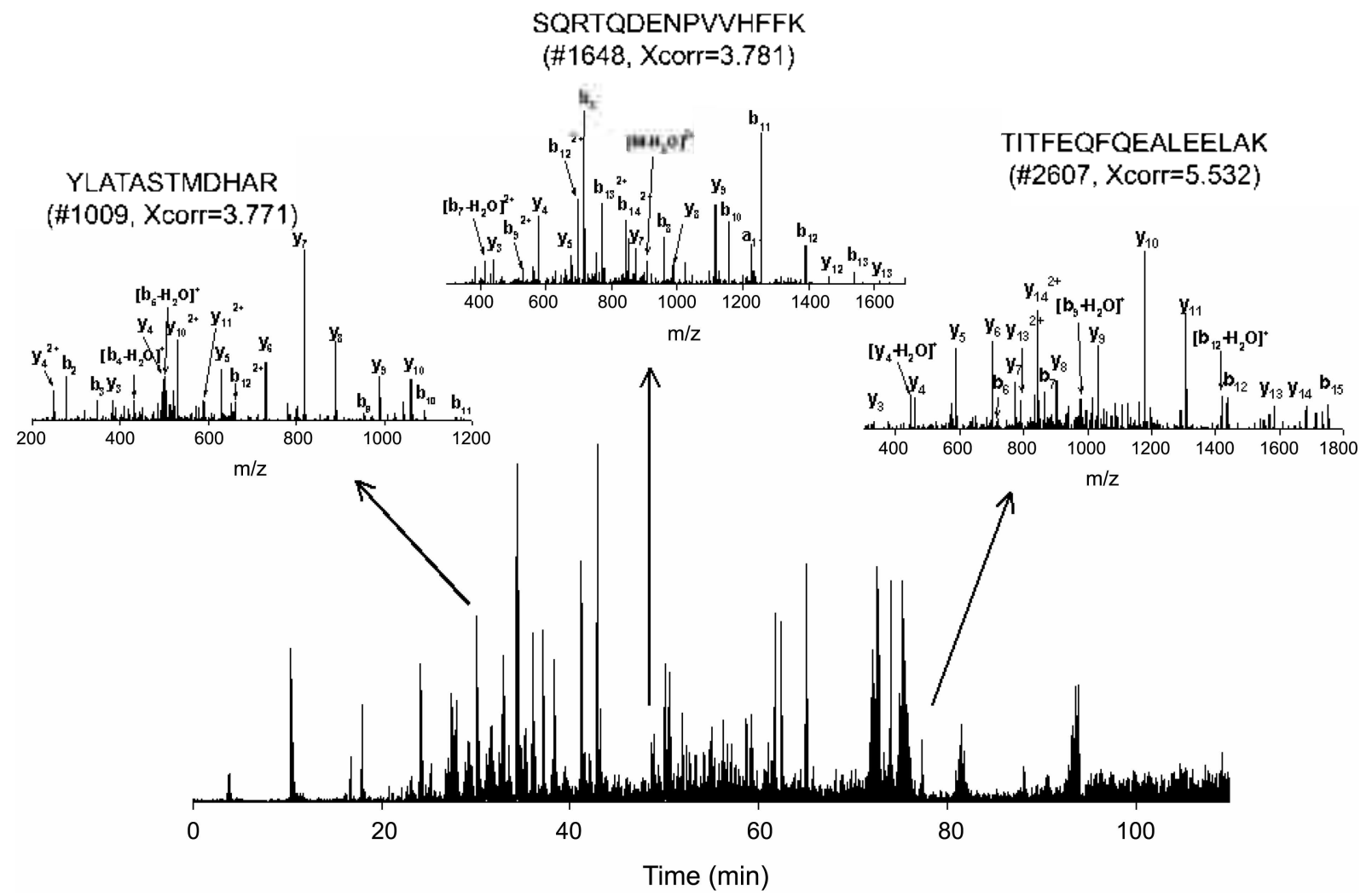

Figure 2. Chromatogram of tryptic digestion of synaptic vesicles in ERPLC. The peak height in the chromatogram represents relative abundance. Confident peptide assignments were exemplitied by a few representative MSA MS spectra.

organelles with higher density such as mitochondria or nucleus were removed in high speed centrifugation step (Fig. IC), and not observed in the electron microscopy of the purified sample.

Proteins from synaptic vesicle fraction were precipitated and treated with trypsin, and the resulting peptides were

A
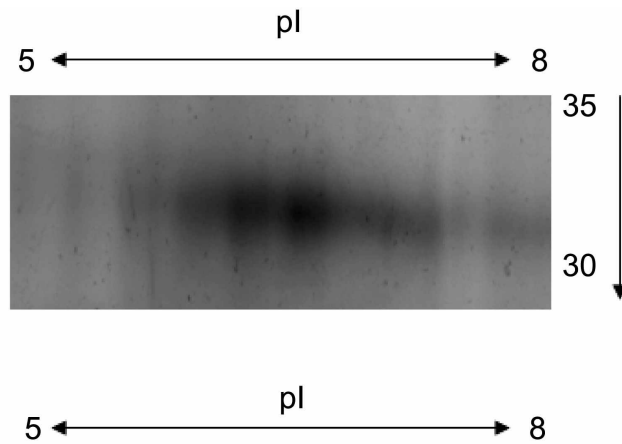

B
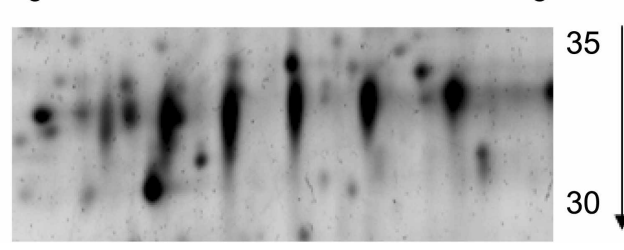

$\mathrm{kDa}$

Figure 3. Improvement of resolution in 2DE gel, ( $($ ) $2 \mathrm{D}) \mathrm{L}$ inage ol synaptic vesicle proteins prepared from general lysis solution $(8 \mathrm{M}$ urea. $4 \%$ CHAPS. $20 \mathrm{mM}$ DTT). (B) 2DF, image of synaptic vesicle proteins prepared from lysis solution ( $7 \mathrm{M}$ urea $2 \mathrm{M}$ 'l hiourea. $4 \%$ (IINPS. $2 \mathrm{mM}$ tributy Iphosphine) and de-contamination. analyzed by CRPLCMS/MS method. A chromatogram of an LC/MS/MS experiment using tryptic peptides from the synaptic vesicle proteins was shown in Figure 2 with three representative MS/MS spectra. As a whole, seventy-five proteins were identified from the initial database search using the filtering criteria described in "Experimental Section", and 18 proteins were finally identified as positive hits by manually inspecting the MS/MS spectra after removing low confidence proteins. For the proteome analysis using 2DE, proteins from the prepared synaptic vesicle fraction was extracted from membrane and fully dissolved before further analysis. Optimum separation of synaptic vesicle proteins in $2 \mathrm{DE}$ was obtained by the membrane extraction with high concentration of urea. thiourea, [']"] and stepwise application of high voltage during IEF as described in "Experimental Section" (Fig. 3). Using the optimized electrophoresis condition, 500 detectable protein spots were separated in 2DE gel (Fig. 4). Among them. 150 spots, which were well separated with measurable intensity in silver stained gel, were picked and undergone mass analysis.

Identification of protein by 20E/MALDI-TOF-MS and CRPLC/MS/MS analysis. The protein spots isolated from the 2DE gel were digested by trypsin and the resulting peptides were analyzed by MALDI-1OH/MS. Among the 150 protein spots detected on 2DE gel, 52 spots were successfully identified. Others were poorly recovered from the gel and generated only a few MS peaks which were not 


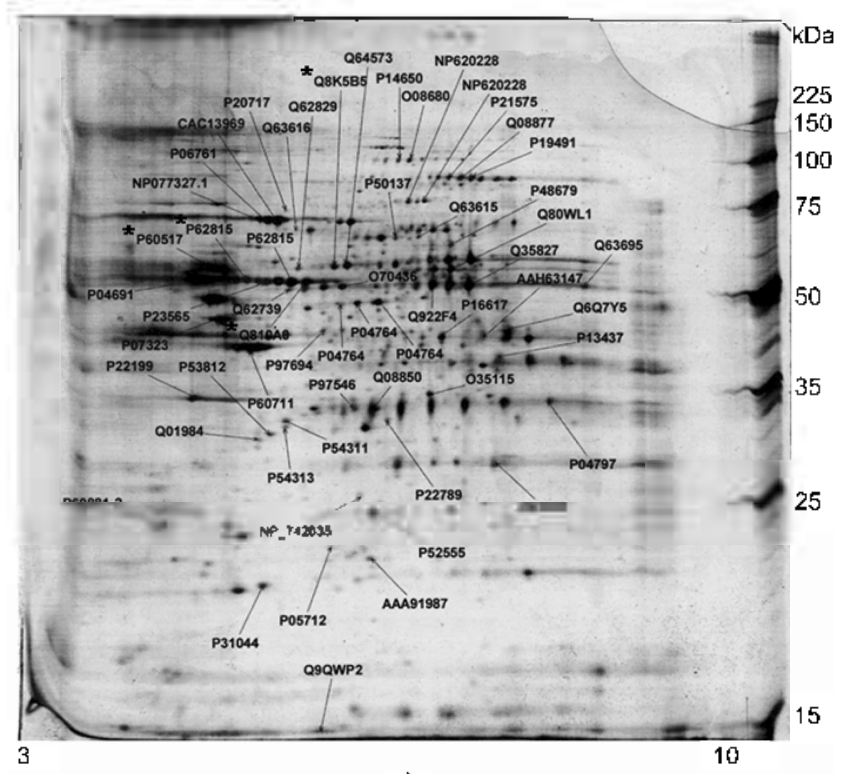

pl

Figure 4. 21) map of rat brain synaptic vesicle protein. Proteins from ral synaptic vesickes brains were separated on at $\mathrm{pH}$ 3-10 nonlincar $[P G$ strip. followed by a $10 \%$ PACiE. as described in Materials and Methods. The gels were stained with silver nitrate. and the visualized spots were analyzed by MAI.III-MS. The aceession numbers from prokein datahase (httpy/kr.expisy.ory/ sprot or $h t t p / / 4 w w$ went.nlm.nih.gow/) indicate the identified protein spots.

sufficient for mass fingerprinting with statistical confidence. The accession numbers of 52 identified protein spots are indicated on 2DE gel (Fig. 4), and the identified proteins are listed in Table I along with name, function, and the accession number, isoelectric point, molecular weight, percent of coverage, Mowse score, and the sequences of peptide hits. Proteins that were identified by $\mathrm{cRPLC} / \mathrm{MS} / \mathrm{MS}$ database analysis are also indicated in Table 1. The identified proteins have more than $95 \%$ confidence level. Only two proteins (Vacuolar AIP synthase subunit B and actin) were identified by both methods. The low percentage of overlapping proteins in the two analytical methods indicates that certain proteins are preferentially well-resolved in particular analytical methods, and different analytical methods should be applied to identify the maximum number of proteins in specific sample.

Among the identified proteins, proteins related to the vesicle trafficking were of particular interest. The SNARE complex has been responsible for the fusion of synaptic vesicles to plasma membrane, and syntaxin, SNAP-25. synapsin, and VAMP-2 are known as the key components of SNARE complex. ${ }^{50}$ Al] of these components involved in the trafficking and fusion of synaptic vesicles are identified in this study. Besides, proteins implicated to vesicle trafficking such as dynamin and r-vsp33 are detected. Among the vesicle related proteins, Vacuolar A'P synthase subunit B. which is responsible for the energy production and acidifying intracellular compartments, showed strong intensity of protein spot in $2 \mathrm{DEE}$ gel indicating that the protein is highly expressed in synaptic vesicles (data not shown).

The major excitatory and inhibitory neurotransmitters in the brain, glutamate and $\mathrm{GABA}$, activate both ionotropic (ligand-gated ion channels) and metabotropic ( $G$ proteincoupled) receptors, and are generally associated with neuronal communication in the mature brain. ${ }^{51}$ In this study, 12 kinds of receptors, transporters and signaling proteins are identified. They are mineralocorticoid receptor, which is one of corticosteroid receptors and highly expressed in the hippocampus. ${ }^{52}$ ephrin type-A receptor, G-protein $\alpha_{13}, \beta_{1}$. $\beta_{2}$, and GABA receptor-associated protein and glutamate transporter. Specially GABA(A) receptor-associated protein and glutamate transporter (GLT Ib) showed high expression level in 2DE gel analysis. Also, senescence marker protein$30\left(\mathrm{SMP}^{3}-30\right)$ and calınodulin 1 , which are related to calcium signaling, are identified.

Among the identified proteins, cytoskeleton proteins, such as actin, and $\alpha$-internexin are highly expressed proteins and frequently observed in proteomic analysis. ${ }^{53}$ They are also related to the regulation of morphology and synaptic function. Especially, actin and its binding partners are involved in the release of neurotransmitters at synapses. ${ }^{\text {s.1 }}$ Besides cytoskeleton proteins, various enzymes involved in metabolisin of carbohydrate, nucleic acid or lipid, energy generation or protein processing are identified. It is noticeable that Hect domain/RLD4 (Q810A0), which is involved in ubiquitin cycle, is highly expressed based on the protein intensity in 2DE gel (data not shown). Since protein ubiquitination is involved in the regulation of vesicle trafficking as well as in the coordination of protein turnover with synaptic function in nerve terminals. ${ }^{55}$ Hect domain RLD4 may be responsible for the biogenesis of synaptic vesicles in brain as previously suggested.

\section{Discussion}

Comparison of identified proteins with previously reported synaptic proteins. Previous analyses of rat synaptic proteome reported 36 to 1131 proteins depending on the sample and analysis methods. When the proteins identified in this study are compared with them. less than $10 \%$ of the reported proteins from synaptosine or post synaptic density fraction are overlapped with the proteins identified in this study (lable 2). The low percentage of overlapped proteins in different reports suggests that the methods for sample preparation and mass analysis significantly affect the kinds and range of identified proteins in each proteome analysis. It is noticeable that $25 \%$ of proteins from membrane enriched fraction of synaptic vesicle ${ }^{88}$ are identified in this study (lable 3 ). The relatively high percentage of overlap might be due to the fact that both analyses used the same membrane enriched fractions. Twenty seven proteins out of 68 identified proteins have not been reported previously. They include proteins in involved in vesicle trafficking (Q008850), signaling process ( $P 22199$, Q6Q7Y5, O08680. Q03336, Q80WL1, XP_001073968), or structural protein (XP_341747). Particularly, 6 out of 9 unconfirmed 
Table 1. Tabular presentation of proteins found in SGV fraction

\begin{tabular}{|c|c|c|c|c|c|c|c|}
\hline $\mathrm{ID}^{\mathrm{a}}$ & Name & Function & pI & IS & $\because \mathrm{C}$ & Monise & Peptides \\
\hline \multicolumn{8}{|c|}{ V'esicle, sụnapse and neuron } \\
\hline Q08850 & Syntaxin-4 & Docking of synaptic vesicles & 5.8 & 34209 & 28 & $8.95 E+02$ & - \\
\hline P21575 & Dỵnamin-1 & Vesicular trafficking processes & 6.3 & 95928 & 14 & $9.89 \mathrm{E}+03$ & - \\
\hline 008877 & Dynamin-3 & Vesicular trafficking processes & 7.6 & 95596 & 4 & $7.13 \mathrm{E}+12$ & - \\
\hline Q63616 & $\begin{array}{l}\text { Facuolar protein sorting } \\
33 \mathrm{AB}\end{array}$ & $\begin{array}{l}\text { Protein trafficking. membrane } \\
\text { docking fusion }\end{array}$ & 6.4 & 70694 & 18 & $1.14 \mathrm{E}-05$ & - \\
\hline P19491 & $\begin{array}{l}\text { Glutamate receptor } 2 \\
\text { [Preeursor] }\end{array}$ & $\begin{array}{l}\text { Communication from a neuron } \\
\text { to a target }\end{array}$ & 7.1 & 98689 & 13 & $1.56 \mathrm{E}-05$ & - \\
\hline P63045 & VALIP-2 & $\begin{array}{l}\text { Ttargeting andior fusion of } \\
\text { transport vesicles to their target } \\
\text { membrane }\end{array}$ & 8.0 & 12690 & 16.3 & - & PPAAPAGEGGPPAPPPNLTSNR \\
\hline P09951-2 & Synapsin-1B & $\begin{array}{l}\text { Coating of synaptic vesicles. } \\
\text { Releasing of neurotrasmitter }\end{array}$ & 9.8 & 69909 & 7.8 & $=$ & $\begin{array}{l}\text { DASPGRGSHSQTPSPGALPLGR: } \\
\text { T]YATEPFIDAKYDYR: TYATAEPFIDAKYDVR : } \\
\text { V]LLYIDEPHTDWAK: }\end{array}$ \\
\hline P02688-1 & $\begin{array}{l}\text { Isofonm } 1 \text { of Hyelin } \\
\text { basic protein } \mathrm{S}\end{array}$ & $\begin{array}{l}\text { Assembly of an optinized. } \\
\text { biochemically functional } \\
\text { myelin membrane }\end{array}$ & 11.2 & 75832 & 66.2 & . & 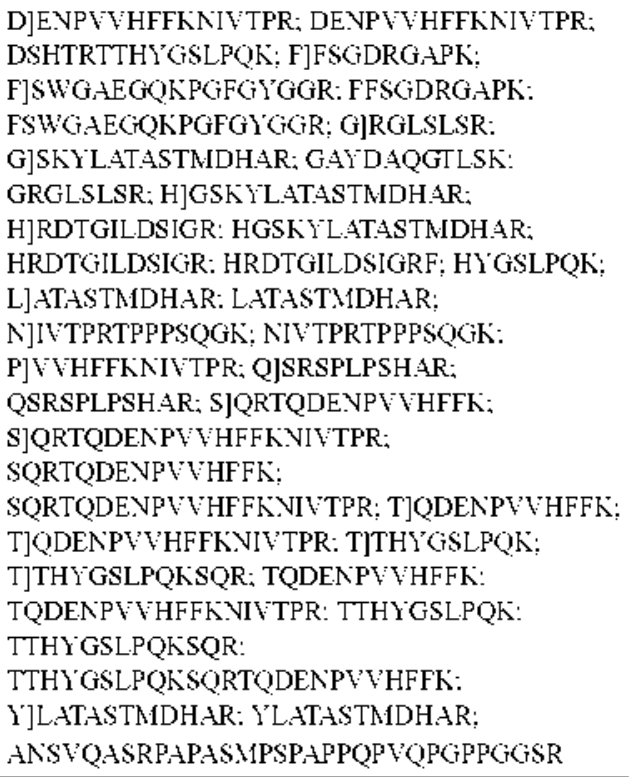 \\
\hline \multicolumn{8}{|c|}{ Receptors, transporters and signaling proteins } \\
\hline P22199 & $\begin{array}{l}\text { Mineralocorticoid } \\
\text { rečptor }\end{array}$ & $\begin{array}{l}\text { Receptor for } \\
\text { mineralocorticoids and } \\
\text { glucocorticoids }\end{array}$ & 7.5 & 106738 & 12 & $8.62 \mathrm{E}-03$ & \\
\hline P54311 & $\mathrm{G} \beta_{\mathrm{l}}$ & $\begin{array}{l}\text { Modulator or transducer in } \\
\text { various signaling systems }\end{array}$ & 5.5 & 37393 & 40 & $1.54 \mathrm{E}+06$ & \\
\hline P54313 & $\mathrm{G} \beta_{2}$ & $\begin{array}{l}\text { Modulator or tratsducer in } \\
\text { various signaling systems }\end{array}$ & 5.6 & 37331 & 47 & $4.72 \mathrm{E}+07$ & \\
\hline Q6Q7Y5 & $\mathrm{G} \alpha_{l s}$ & $\begin{array}{l}\text { Modulator or trausducer in } \\
\text { various signaling sstems }\end{array}$ & 8.4 & 44012 & 10 & $1.58 \mathrm{E}+02$ & \\
\hline P31044 & PEBP-1 & $\begin{array}{l}\text { Increases the production of } \\
\text { choline acetyiltransferase }\end{array}$ & 5.5 & 20802 & 74 & $9.17 \mathrm{E}-(14$ & \\
\hline 008680 & $\begin{array}{l}\text { Ephrin type-A receptor } \\
3 \text { [Precursor] }\end{array}$ & $\begin{array}{l}\text { Development of the central } \\
\text { nervous }\end{array}$ & 6.5 & 110229 & 9 & $4.44 \mathrm{E}-0.3$ & \\
\hline Q8K5B5 & $\begin{array}{l}\text { Glutamate transporter } \\
\text { GLT1b }\end{array}$ & Dicarbostrlic acid transport & 6.2 & 60918 & 24 & $5.49 \mathrm{E}-03$ & \\
\hline P60517 & $\begin{array}{l}\text { G.ABA(A) receptor- } \\
\text { associated }\end{array}$ & $\begin{array}{l}\text { Transport of GABA(A) } \\
\text { receptors }\end{array}$ & 4.9 & 50164 & 25 & $1.79 \mathrm{E}-06$ & \\
\hline Q03336 & $\begin{array}{l}\text { Senescence marker } \\
\text { protein-30 }\end{array}$ & $\begin{array}{l}\text { Regulation of calcium } \\
\text { signaling }\end{array}$ & 6.2 & 12885 & 36 & $1.18 \mathrm{E}-02$ & \\
\hline$Q 62772$ & Tenascin -X & $\begin{array}{l}\text { Receptor binding and signal } \\
\text { transduction }\end{array}$ & 6.4 & 23561 & 31 & $1.22 \mathrm{E}-0.3$ & - \\
\hline
\end{tabular}


Table 1. Continued

\begin{tabular}{|c|c|c|c|c|c|c|c|}
\hline $\mathrm{ID}^{\mathrm{a}}$ & Name & Function & pI & MS & $\because \mathrm{C}$ & Mowse & Peptides \\
\hline Q80WLl & Gliomedin & Transport of phosphate & 7.7 & 59331 & 8 & $2.11 \mathrm{E} 03$ & - \\
\hline XP_00107396 & 8 Similar to calmodulin 1 & $\begin{array}{l}\text { control of a large number of } \\
\text { proteins by } \mathrm{Ca}^{2-}\end{array}$ & 4.1 & 16814 & 45 & $\cdot$ & $\begin{array}{l}\text { A]DQLTEEQIAEFKE.AFSLFDKDGDGTITTK; } \\
\text { SJLGQNPTEAELQDWINEVDADGNGTIDFPEFLT } \\
\text { WMAR: } \\
\text { SLGQNPTEAELQDMINEVDADG.VGTIDFPEFLT } \\
\text { MMAR }\end{array}$ \\
\hline
\end{tabular}

\begin{tabular}{|c|c|c|c|c|c|c|c|}
\hline \multicolumn{8}{|c|}{ Cytoskeleton and cell movenent related protein } \\
\hline P60711 & Actim. eytoplasmic 1 & In various types of eell motility & 5.3 & 41751 & 485.6 & $62.09 \mathrm{E}-08$ & AGFAGDDAPRAVFPSIVGRPR \\
\hline P23565 & $\alpha$-intentexin & Morphogenesis of neurons & 5.2 & 56116 & 17 & $6.06 \mathrm{E}+03$ & \\
\hline$X P \_341747$ & $\begin{array}{l}\text { similar to tubulin } \\
\text { polymerization-promoting }\end{array}$ & $\begin{array}{l}\text { Promotes in vitro the } \\
\text { polymerization of tululinsy }\end{array}$ & 9.4 & 23545 & 7.3 & $\cdot$ & TJITFEQFQEALEELAK: TITFEQFQEALEELAK \\
\hline \multicolumn{8}{|l|}{ Enzyme } \\
\hline$N_{P} 742035$ & $\begin{array}{l}\text { Glutathione s-transferase } \\
\text { Mus } 5\end{array}$ & $\begin{array}{l}\text { Conjugating GSH with a } \\
\text { electrophilic substrates }\end{array}$ & 6.3 & 26629 & 27 & $4.81 \mathrm{E}+02$ & \\
\hline Q64573 & $\begin{array}{l}\text { Liver earboxylesterase } 4 \\
\text { [Precursor] }\end{array}$ & $\begin{array}{l}\text { Detoxification of xenobiotics. } \\
\text { activation of ester, amides }\end{array}$ & 6.3 & 62275 & 17 & $3.65 E+04$ & \\
\hline Pl 4650 & $\begin{array}{l}\text { Thyroid peroxidase } \\
\text { [Precursor] }\end{array}$ & Osidative stress & 6.6 & 101461 & 14 & $6.94 \mathrm{E}+(14$ & \\
\hline$P 50137$ & Transketolase & $\begin{array}{l}\text { Link glycolytic and pentose- } \\
\text { phospliate pathways }\end{array}$ & 7.2 & 67644 & 7 & $1.36 \mathrm{E}+(12$ & \\
\hline Q01984 & $\begin{array}{l}\text { Histanine } \mathrm{N} \text { - } \\
\text { metlyyltransferase }\end{array}$ & Degrading histanine & 5.0 & 33942 & 18 & $4.04 \mathrm{E}+02$ & \\
\hline Q6P7So & Pkn12 & Glyeolysis & 8.0 & 52936 & 5.7 & $\cdot$ & AATESFASDPILYRPYAVALDTKGPEIR \\
\hline$P 09606$ & Glutamine synthetase 1 & $\begin{array}{l}\text { ATP }+\mathrm{L} \text {-glutamate }+\mathrm{NH}_{3}= \\
\mathrm{ADP}+\text { phosphate }-\mathrm{L}- \\
\text { glutamine }\end{array}$ & 6.6 & 42268 & 2 & $\cdot$ & SASIRIPR \\
\hline NP_ 955417 & $\begin{array}{l}\text { Dihydrolipos!l } \\
\text { delyydrogenase }\end{array}$ & $\begin{array}{l}\text { Component of the glycine } \\
\text { cleavage system (By } \\
\text { similarity). }\end{array}$ & 7.9 & 540138 & 4.7 & $\cdot$ & SDQPIDADVTVIGSGPGGYYAAIK \\
\hline \multicolumn{8}{|c|}{ Energy generation and provide } \\
\hline $\mathrm{P} 25809$ & $\begin{array}{l}\text { Creatine kinase, ubiquitous } \\
\text { [presursor] }\end{array}$ & $\begin{array}{l}\text { Transfer of phosphate bettveen } \\
\text { ATP and various phosphogens }\end{array}$ & & 47029 & 8.1 & $\cdot$ & $\begin{array}{l}\text { LSEMTEAEQQQLIDDHFLFDKPVSPLLTAAGMA } \\
\mathrm{R}\end{array}$ \\
\hline P10719 & $\begin{array}{l}\text { ATP synthase subunit } \beta \text {. } \\
\text { mitochondrial [precursor] }\end{array}$ & $\begin{array}{l}\text { Producing of ATP from } A D P \text { in } \\
\text { the presence of a proton } \\
\text { gradient }\end{array}$ & 15.2 & 56350 & 2.8 & - & LJVLEVAQHLGESTVR: LVLEVAQHLGESTVR \\
\hline Q811. & Lysosomal ATPase & Energ: production & 6.8 & 12034 & 13.4 & - & A]SQSQGIQQLLQAEK \\
\hline $\mathrm{P} 62815$ & $\begin{array}{l}\text { Vacuolar ATP synthase } \\
\text { subunit B. brain isoform }\end{array}$ & $\begin{array}{l}\text { Non-catalytic subunit of the } \\
\text { peripheral Vl comples of } \\
\text { vaeuolar ATPase }\end{array}$ & 5.6 & 56546 & 402.9 & $94.63 \mathrm{E}+10$ & YAEIFHLTLPDGTKR \\
\hline P01946 & Henoglobin subunit $\sigma-12$ & Oxygen transport & 7.9 & 15327 & 62 & $\cdot$ & $\begin{array}{l}\text { A].ADHVEDLPGALSTLSDLHAHK: } \\
\text { A]ADHVEDLPGALSTLSDLHAHKLR: } \\
\text { AADHYEDLPGALSTLSDLHAHK: } \\
\text { FLASVSTVLTSKY; I]GGHGGEYGEEALQR: } \\
\text { IGGHGGEYGEEALQR: LPGALSTLSDLHAHK: } \\
\text { MJFAAFPTKTYFSHIDVSPGSAQVK: } \\
\text { WFAAFPTTKTYFSHDVSPGSAQVK: } \\
\text { PJTTKTYFSHIDVSPGSAQVK: } \\
\text { T]YFSHIDVSPGSAQV: TYFSHDVSPGSAQVK: } \\
\text { V]LSADDKTNIK; VLSADDKTNIK }\end{array}$ \\
\hline P0)2091 & Hemoglobin subunit $\beta$ l & Oxygen transport & 8.0 & 15978 & 50 & & 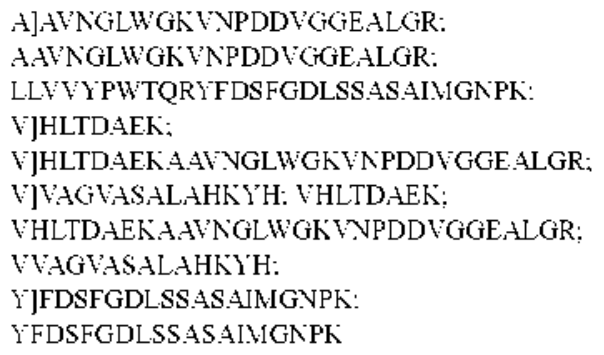 \\
\hline
\end{tabular}


Table 1. Continued

\begin{tabular}{|c|c|c|c|c|c|c|}
\hline $\mathrm{ID}^{\mathrm{a}}$ & Name & Function & $\mathrm{pl}$ & MS & $\because \mathrm{C}$ & Peptides \\
\hline \multicolumn{7}{|c|}{ Carbolyłdrate. Nucleic acid Hetabolism } \\
\hline $\mathrm{P} 04764$ & $\alpha$ enolase & Glycolysis & 6.2 & 47116 & 29 & $1.47 \mathrm{E}+09$ \\
\hline P07323 & $\gamma$ enolase & Glycolysis & 5.0 & 47141 & 23 & $1.80 \mathrm{E}+04$ \\
\hline P16617 & Plosphoglyeerate kinase & Glycolysis & 7.5 & 44555 & 17 & $4.94 \mathrm{E}+02$ \\
\hline $\mathrm{P} 04797$ & G.APDH & Glyeolysis & 8.4 & 35836 & 27 & $4.85 E+02$ \\
\hline \multicolumn{7}{|c|}{ Lipid netabolisn1 } \\
\hline P13437 & $\beta$-ketothiolase & Fatty acid beta-oxidation cycle & 8.1 & 41871 & 19 & $2.43 E+03$ \\
\hline $\mathrm{P} 22789$ & $\begin{array}{l}\text { Alcoliol sulfo-transferase } \\
\text { A }\end{array}$ & $\begin{array}{l}\text { Catalyzes sulfation of } \\
\text { lyłdroxysteroids and senobiotics }\end{array}$ & $\begin{array}{l}7.6 \\
s\end{array}$ & 33252 & 22 & $8.28 \mathrm{E}+03$ \\
\hline \multicolumn{7}{|c|}{ Nucleotide processing } \\
\hline Q63520 & $\begin{array}{l}\text { Synaptonenal conplex } \\
\text { protein } 3\end{array}$ & $\begin{array}{l}\text { Play inportant roles in } \\
\text { cliromosome condensation }\end{array}$ & 8.7 & 29347 & 18 & $9.82 \mathrm{E}+02$ \\
\hline Q63695 & $\begin{array}{l}\text { Ostamer-binding TF } \\
\text { [Fragnent] }\end{array}$ & $\begin{array}{l}\text { Transcription factor for } \sin R{ }^{\prime} A \\
\text { etc }\end{array}$ & 8.6 & 51223 & 8 & $1.33 \mathrm{E}+02$ \\
\hline P48679 & Lamin A & $\begin{array}{l}\text { Components of the nuclear } \\
\text { lamina }\end{array}$ & 6.2 & 71642 & 19 & $2.44 E+03=$ \\
\hline 070436 & $\begin{array}{l}\text { Mothers against DPP } \\
\text { homolog } 2\end{array}$ & $\begin{array}{l}\text { Regulation of transcription, } \\
\text { DNA-dependent }\end{array}$ & 6.1 & 52240 & 9 & $2.45 \mathrm{E}+02$ \\
\hline
\end{tabular}

Protein processing. folding and modification

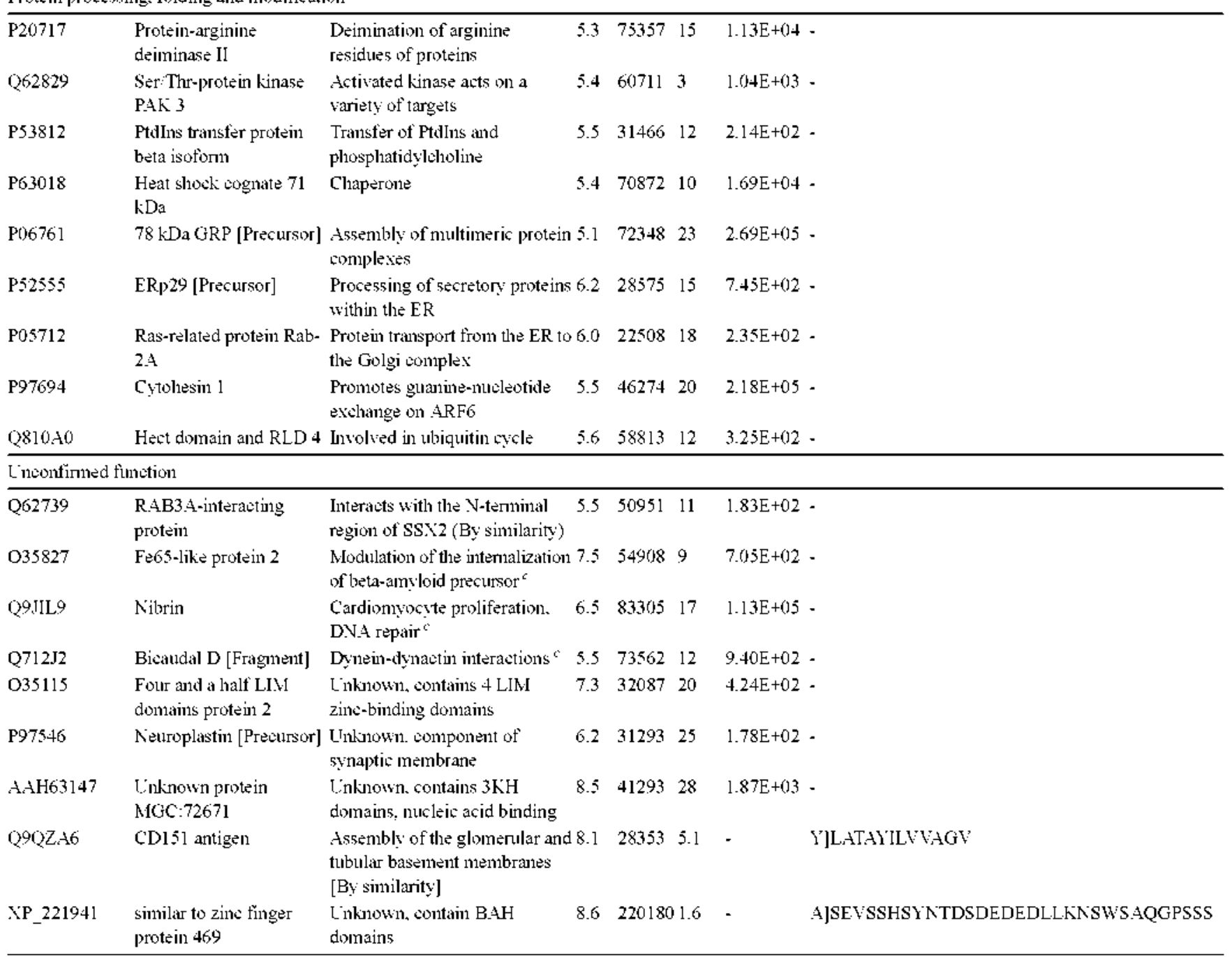

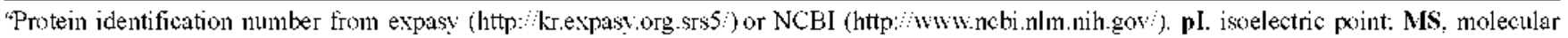
weight of protein (Dalton): \%C, percent sequence corerage by measured masses; Mow se, score from MS-FIT database (littp- prospector.ucsf edul) 
Table 2. Comparison of proteomic analy sis of synaptic vesicle fraction

\begin{tabular}{|c|c|c|c|c|c|c|c|c|}
\hline & Stevens, $2003^{{ }^{6}}$ & $\mathrm{Li}, 2004$ & $\begin{array}{l}\text { Tordant, } \\
2004^{30}\end{array}$ & $\begin{array}{l}\text { Coughenour, } \\
2004^{38}\end{array}$ & $\begin{array}{l}\text { Witzmann, } \\
2005^{\circ 8}\end{array}$ & $\begin{array}{l}\text { Schrimpf, } \\
2005^{\circ 9}\end{array}$ & $\mathrm{Li}, 2005^{\circ / 1}$ & This study \\
\hline Sample & $\begin{array}{l}\text { Synaptic plasma } \\
\text { membrante }\end{array}$ & PSD & PSD & $\begin{array}{l}\text { Synaptic vesicle } \\
\text { membrane }\end{array}$ & Synaptosome & Sỵnaptosome & PSD & $\begin{array}{l}\text { Synaptic } \\
\text { vesicle }\end{array}$ \\
\hline Method & $\begin{array}{l}\text { 1D, MALDI MS } 2 \\
\& \text { LC MS/MS }\end{array}$ & $\begin{array}{l}\text { D, MALDI MS/MS } \\
\& \text { ICAT, LC MS }\end{array}$ & $\begin{array}{c}\text { LC } \\
\text { MS/MS }\end{array}$ & $\begin{array}{l}\text { 2D, LC } \\
\text { MS/MS }\end{array}$ & $\begin{array}{l}\text { 2D, MALDI MS } \\
\& \text { LC MS/MS }\end{array}$ & $\begin{array}{l}\text { ICAT LC } \\
\text { MS/MS }\end{array}$ & $\begin{array}{l}\text { ICAT LC } \\
\text { MS/MS }\end{array}$ & $\begin{array}{l}\text { 2D, MALDI MS } \\
\& \text { LC MS/MS }\end{array}$ \\
\hline ID & 108 & 170 & 452 & 36 & 317 & 1131 & 130 & 68 \\
\hline Uniq. & $\begin{array}{l}\text { Q08850, P22199, } \\
\text { P97694, } 035827,\end{array}$ & $\begin{array}{l}607 Y 5,008680, Q 0 \\
935827,035115, Q 6\end{array}$ & $\begin{array}{l}3336,080 \\
2739, Q 90\end{array}$ & $\begin{array}{l}\text { WL1, Q64573,Pl4 } \\
\text { ZA } 6, X_{2} 341747\end{array}$ & $\begin{array}{l}650, \mathrm{P} 22789, \mathrm{Q} 635 \\
\mathrm{AAH} 63147, \mathrm{XP}_{2} 2\end{array}$ & $\begin{array}{l}20, Q 63695,070 \\
21941, X_{-} 001\end{array}$ & $\begin{array}{l}436, \mathrm{P} 20717 \\
973968, \mathrm{NP}\end{array}$ & $\begin{array}{l}\text { P53812,Q810A0 } \\
955417, Q 811 \mathrm{~A} 7\end{array}$ \\
\hline
\end{tabular}

ID. Total number of identifies protein; Uniq.. Unique protein list: PSD. Postsynaptic density:

Table 3. List of membrane protein

\begin{tabular}{|c|c|c|c|c|c|}
\hline Name & Domains $^{a}$ (predicted) & Subcellular location ${ }^{b}$ & TM & PTM & $\mathrm{M}$ \\
\hline Syntasin-4 & SyIN, t-SNARE, & $\begin{array}{l}\text { Membrane; single-pass type IV } \\
\text { membrane protein (Potential). }\end{array}$ & 1 & - & I \\
\hline SNAP-25A & $\mathrm{CC}, \mathrm{t}-\mathrm{SNARE}$ & Synaptic vesicle & - & Palmitoylated & $\mathrm{P}$ \\
\hline Vacuolar protein sorting $33 \mathrm{~A}$ & Secl & $\begin{array}{l}\text { peripheral membrane protein associated } \\
\text { with late endosomes/ly sosomes }\end{array}$ & & & $\mathrm{P}$ \\
\hline Vacuolar protein sorting $33 \mathrm{~B}$ & Secl & $\begin{array}{l}\text { peripheral membrane protein associated } \\
\text { with late endosomes/y sosomes }\end{array}$ & & & $\mathrm{P}$ \\
\hline Glutamate receptor 2 [Precursor] & $\begin{array}{l}\text { Signal peptide, ANF_receptor, } \mathrm{PBPe} \text {, } \\
\text { LIg_chan }\end{array}$ & $\begin{array}{l}\text { membrane; multi-pass membrane } \\
\text { protein }\end{array}$ & 3 & Palmitoylated & I \\
\hline VAMP-2 & Coiled coil, Synaptobrevin, & $\begin{array}{l}\text { Type IV membrane protein. Neuronal } \\
\text { synaptic vesicles }\end{array}$ & 1 & & I \\
\hline $\begin{array}{l}\text { Epluin type-A receptor } 3 \\
\text { [Precursor] }\end{array}$ & $\begin{array}{l}\text { Signal peptide, EPH_lbd, FN3, TyrKc, } \\
\text { SAM }\end{array}$ & $\begin{array}{l}\text { type i membrane protein. the short } \\
\text { isofonm is secreted }\end{array}$ & 2 & & I \\
\hline Glutannate transporter GLTlb & SDF & $\begin{array}{l}\text { membrane; multi-pass membrane } \\
\text { protein }\end{array}$ & 10 & & I \\
\hline GABA(A) receptor-associated & $\mathrm{MAPl} \mathrm{LC}_{3}$ & $\begin{array}{l}\text { membrane-associated through a lipid } \\
\text { anchor }\end{array}$ & - & $\begin{array}{l}\text { Lipid } \\
\text { modification }\end{array}$ & $\mathrm{P}$ \\
\hline Gliomedin & Collagen, OLF & $\begin{array}{l}\text { membrane; single-pass membrane } \\
\text { protein }\end{array}$ & 1 & $\begin{array}{l}\text { Hydroxylated, } \\
\text { disulfide bondins }\end{array}$ & I \\
\hline $\begin{array}{l}\text { Liver carbosylesterase } 4 \\
\text { [Precursor] }\end{array}$ & coesterase & $\begin{array}{l}\text { Microsomal membrane, lumen of } \\
\text { endoplasmic reticulum }\end{array}$ & 1 & & I \\
\hline Thyroid peroxidase [Precursor] & $\begin{array}{l}\text { Signal peptide, An_peroxidase, CCP, } \\
\text { EGF_CA, }\end{array}$ & single-pass type i membrane protein & 1 & Heme & I \\
\hline $\begin{array}{l}\text { ATP synthase } \beta \text { chain, } \\
\text { [Precursor] }\end{array}$ & $\begin{array}{l}\text { ATP-synt_ab_N, AAA, } \\
\text { ATP-synt_ab_C }\end{array}$ & mitochondrion & - & & $\mathrm{P}$ \\
\hline$\alpha$ enolase & Enolase_N, Enolase_C & can translocate to the plasma membrane & 1 & & I \\
\hline$\gamma$ endase & Enolase_N, Enolase_C & can translocate to the plasma membrane & 1 & & I \\
\hline $\begin{array}{l}\text { Dihydrolipoamide } \\
\text { delhydrogenase }\end{array}$ & GIDA, Pyr_redox & mitochondrion & 1 & & I \\
\hline ERp29 [Precursor] & Signal peptide, Erp29 & endoplasmic reticulum lumen & 1 & & I \\
\hline Bicaudal D [Fragment] & Coiled coil & associated with intracellular membranes & - & & $\mathrm{P}$ \\
\hline CDI5I antigen & Tetrasparnin & multi-pass membrane protein & 3 & & $\mathrm{I}$ \\
\hline
\end{tabular}

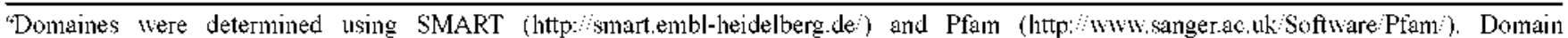
abbreviation key: Syn. Syntavin N-terninal domain: t-SN.ARE. target membrane soluble N-ethylmaleimide attachment protein receptor, CC., Coiled coil; Sec1. Domain named after the S. cerevisiae SECl gene product: A.MF_receptor. Atrial natriuretic factor receptor, PBPe. Eukaryotic homalogues of bacterial periplasmic substrate binding proteins: LIg_chan. Ligand-gated ion channel: EPH_lbd. Ephrin receptor ligand binding domain: F.3. Fibronectin type III domain; TyKK, Ty rosine kinase catalytic domain; SAM, Sterile alpha motif; SDF, Sodium dicarboxylate symporter family: MAP1 LC3. Microtubule associated protein lAIB, light chain 3; Collagen. Collagen triple helix repeat: OLF, Olfactomedin-like domain: COesterase. Carboxylesterase: An_peroxidase. Animal haem peroxidase : CCP. Donain abundant in complement control proteins; EGF_CA. Calcium-binding EGF-like domain: ATP-synt_ab. ATP synthase alpha beta family; ATP-gua PtransN. ATP:guanido phosphotransterase. N-terminal domain: ATP-gua_Ptrans. ATP:guanido phosphotransferase, C-terninal cataltic domain; ATP-synt_ab_x, ATP synthase alpha beta family; betabarrel domainAAÄ; ATP-ssnt_ab_C, ATP synthase alpha beta chain, $\mathrm{C}$ tenminal domain: Enolase_x, Enolase. N-terminal domain: Enolase_C: Enolase. C-terminal domain; GIDA. Glucose inhibited division protein A: Pyr redox. Pyridine nucleotide-disulphide oxidoreductase: Erp29. Endoplasmic reticulum protein ERp29. C-terninal domain: Tetraspannin. Tetraspanin family. ${ }^{b}$ Subcellular location were determined using SOURCE (hittp isource stanford edu). 
proteins are newly identified proteins in this study. Analysis of the molecular function of these proteins would provide detailed information on the process of vesicle trafficking in synapses.

Functional estimation of unknown proteins. Among the 68 identified proteins from rat synaptic vesicle fraction. the cellular function of 9 proteins not confirmed (Table 1). The function of these proteins was further estimated from the putative binding partners of these proteins, expression profile or structural homologues. Among them, 3 proteins (Bicaudal D. Neuroplastin and RAB3A-interacting protein) are implicated to be involved in vesicle trafficking or biogenesis. Bicaudal D (BICD: Q7I2J2) has no distinct functional domain. However, homolognes proteins of Bicaudal D (Bicaudal Dl and 2) could bind to the small GTPase. Rab6. as well as to dynein-dynactin complexes indicating that it may recruit dynein motor to Rab6-positive membranes of the Golgi apparatus and cytoplasmic vesicles ${ }^{56.58}$ RAB3Ainteracting protein (Q62739) has Sec2p donain. a GDP-GTP exchange factor, and endoplasmic reticulum targeting domain. Since Sec2p is involved in vesicular transport at the post-Golgi stage ${ }^{*-9}$ and interacts with small GTPases such as Rab3A. which is associated with secretary vesicle membranes and regulates exocytosis, ${ }^{6 i}$ RAB3A-interacting protein may be involved in the control of vesicular secretion. transport and exocytosis. Neuroplastin (P97546) is a type I transmembrane protein containing inumunoglobulin like domain. It has been identified as a major component of synaptic membranes from rat forebrain, and implicated to have an essential role in implementing long-term changes in synaptic activity, possibly by means of a homophilic adhesion mechanism. ${ }^{61}$ More biochemical and genetic analysis would reveal the precise function of these proteins.

Complementation of cRPLC/MS-MS and 2DE/MALDITOF-MS of proteome analysis. Although there are only a few proteins commonly identified by both proteome analy sis methods in this study. other investigations also revealed that 2DE coupled with MALDI-TOF-MS and chromatography coupled with ESI-MS/MS usually identified complementary sets of proteins from the same sample source. ${ }^{6.63}$ It is widely accepted that no single analytical approach will identify all the major proteins in any proteome ${ }^{\hat{6} \hat{}}$ It is basically due to the difference of ionization mode. In MALDI, almost all peptides are singly-charged. while in ESI longer peptides usually' involve doubly or triply'-charged ${ }^{64.66}$ Furthermore the ESI analysis includes only those peptides definitively identified wa MS/MS fragmentation. whereas the MALDI identification is by mass alone ${ }^{6 t}$

In summary, we have analyzed proteins from rat brain synaptic vesicles using two different separation methods and mass analysis techuiques. cRPLC/MS/MS and 2DEMALDI-TOF/MS. Most of the identified proteins from each method are not overlap indicating that the efficiency of protein identification varies depending on the extraction and separation methods. This observation suggested that different proteome analysis methods should be applied to identify maximum number of proteins in tissue sample. Among the
27 newly identified proteins in this study, 9 proteins are functionally unknown. Three of the functionally unknown proteins are estimated to involve in trafficking or biogenesis of synaptic vesicles. Further biochemical or genetic analy sis of these proteins would reveal their cellular function in synaptic vesicles.

Acknowledgements. This work was supported by grants from the 2lC Frontier Research Program. Functional Proteonics Research (FPR05B2040). Ministry of Science and Teclunology, Korea. H. M. and S. L. also thanks to Korea Science Foundation grant (R0405821).

\section{References}

1. Heuser. J. E. J. Phnsiol. 1974. 239. 106-108.

2. Heuser. I. E. Thends in Neurosciences 1978. 1. 80-82.

3. Betnett. M. K.: Garcia-Arraras. J. E.: Elferink. L. A.: Peterson. K. Fleming. A. M: Hazuka. C. D: Scheller. R. H. Cell 1993. 74. $863-873$.

4. Risinger. C.: Larhammar, D. Proc. Fatt. Acad Sci. USA 1993, 90. $10598-10602$

5. Jahnt. R:: Südhof. T. C. Amm. Rev: Biochen. 1999. 68. 863-911.

6. Mulholland. J.: Wesp. A.: Riezman1. H.: Botstein. D. Mol. Biol. Cell 1997.8. 1481-1499.

7. Hsu. S. C : Hazuka. C. D: Roth, R: Foletti. D. L.: Heuser, J.; Scheller. R. H. Nimon 1998. 20, 1111-1122.

8. Finger. F. P.: Hughes. T. E.: Nowick. P. Cell 1998. 92.559-571.

9. Novick. P.: Zerial. M. Cw Opin. Cell Biol 1997. 9.496-504.

10. Schimmöller. F.: Simon. I.: Pfeffer. S. R. J. Biol. Chem. 1998. 273. 22161-22164.

11. Echard, A.: Jollivet, F; Martinez, $\mathrm{O} ;$ Lacapère, J. J : Rousselet. A.; Janoueix-Lerosey. I.: Goud. B. Scimce 1998, 279, 580-585.

12. Goumier. H.: Stenmark. H.: Rybirl. V: Lippé. R:: Zerial. M. ENBO J. 1998. 17. 1930-1940.

13. Ray. G. S.: Lee. I. R.: Nwokeji. K.: Mills. L. R.: Goldenring. J. R. Lab. hwest 1997. 77.503-511.

14. Gonzalez, L. Jr: Scheller, R. H. Cell 1999. 96. $755-758$.

15. Shirataki, H.: Kaibuchi, K; Sakoda. T.; Kishida, S.: Yamaguchi. T:: Wada. K.: Miyazaki. M.: Takai. Y. Hol Cell. Biol 1993. 13. 2061-2068.

16. Stahl. B:: Chou. J. H:: Li. C.: Südhof. T. C.: Jahnl. R. EHBBO J. 1996. $15,1799-1809$

17. Wang, Y: Okamoto. M: Schmitz, F: Hofmann. K: Sudhof. T. C. Nature 1997, 388. 593-598.

18. Christoforidis. S.: McBride. H. M.: Burgoyne. R. D.: Zerial. M. Nature 1999. 397.621-625.

19. Simonset1. A.: Lippé. R.: Christoforidis. S.: Gaullier. J. M.: Brech. A.: Callaghan. J:- Toh. B. H.: Murphy: C.: Zerial, M.: Stemmark, H. Nature 1998, 394. $494-498$.

20. Cao. X.: Ballew: N.: Barlowe. C. ElBBO J. 1998. 17.2156-2165.

21. Nelson. D. S.: Alvarez. C.: Gao. Y. S.: García-Mata. R: Fialkowski. E.: Sztul. E. J. Cell Biol. 1998. 143. 319-331.

22. Morel. N. Biol Cell 2003. 95. 453-457.

23. Ziv N. E.: Gamer C. C. Nat. Rew Newosci. 2004. 5. 385-399.

24. Bell. A. W: Ward, M. A: Blackstock, W. P.: Freeman, H. N.; Choudhary, J. S.; Lewis. A. P: Chotai. D.: Fazel, A.: Gushue, J. N.: Paiement. I.: Palcy. S.: Chevet. E.: Lafienière-Roula. M: Solari. R: Thomas. D. Y.: Rowley: A.: Bergeron. T. T. J. Biol. Chent 2001. 276.5152-5165.

25. Garin, J:- Diez, R:; Kieffer. S.: Demine, J. F: Duclos, S.: Gagnon. E.: Sadoul. R.: Rondeau, C.: Desjardins, M. J. Cell Biol. 2001. 152. 165-180.

26. Rabilloud. T. Electrophoresis 1998. 19.758-760.

27. Beranowa-Giorgiantil. S.: Giorgianni. F.: Desiderio. D. M 
Proteonics 2002. 2.534-452.

28. Gauss. C.: Kalkum. M.: Löwe. M.: Lehrach. H.: Klose. J. Electrophonesis 1999. 20.575-600.

29. Klose. J: Nock, C.: Herrmann. M.: Stulhler. K: Mareus, K.: Blüggel. M.: Krause. E: Schalkwyk. L. C.: Rastan, S: Brown. S. D.: Bussow, K: Himmelbalter. H.: Lehrach. H. Nat. Genet. 2002. 30. 385-393.

30. Krapfenbauer. K.: Fountoulakis. M:: Lubec. G. Electrophoresis 2003. 24. 1847-1870

31. Lubec, G: Krapfenbauer K: Fountoulakis. M. Prog Nemobiol. $2003,69,193-211$

32. Tsugita A: Kawakami, T: Uchida, T.: Sakai. T: Kamo, M.: Matsui. T.: Watanabe. Y: Morimasa. T.: Hosokawa. K.: Toda. T. Electrophoresis 2000. 21. 1853-1871

33. Langen. H.: Berndt. P.: Röder. D.: Cairns. N.: Lubec. G.: Fountoulakis. M. Electrophoresis 1999. 20,907-916.

34. Barber D. S.: LoPachin. R. M. Toxicol. Appl. Phamacol. 2004. $201,120-136$.

35. Blondeau. F.: Ritter. B.: Allaire. P. D.: Wasiak. S.: Girard. M.: Hussain. N. K:: Angers. A.: Legendre-Guillemin. V.: Roy. L: Boisment. D.: Kearney. R. E.: Bell. A. W.: Bergeron. J. J.: McPherson, P. S. Proc. Katl. Acad Sci. LSA 2004, 101. 38333838 .

36. Stevens, S. M.. Ir.: Zharikova. A. D.: Prokai. L. Bram. Res. Mol. Brain Res. 2003. 117, 116-128.

37. Jimenez. C. R.: Eyman. M.: Lavina. Z. S.: Gioio. A.: Li. K. W: van der Schors. R. C.: Geraerts. W. P.: Giuditta. A.: Kaplan. B. B.: van Minnen. I. J. Keurochem. 2002.81, 735-744

38. Coughenour, H. D.: Spaulding, R. S.: Thompson, C. M. Proteonics 2004. $4.3141-3155$

39. Jordan. B. A.: Fernholz. B. D.: Boussac. M.: Xu. C.: Grigorean. G: Ziff. E. B.: Neubert. T. A. A fol. Cell Proteontics 2004. 3. 857. 871 .

40. Huttner, W. B.: Schiebler W. Greengard P: De Camilli, P. J. Cell Biol. 1983. 96. 1374-1388.

41. Smith. P. K.: Krolm, R. I. Hermanson, G. T.: Mallia, A. K.: Gartner. F. H.: Provenzano. M. D.: Fujimoto. E. K.: Goeke. N. M.: Olson. B. J.: Klenk. D. C. Andal. Biochem. 1985. 150.76-85.

42. Kim. M. S.: Choie. W. S.: Shin. Y. S.: Yu. M. H.: Lee. S.-W. Bull. Korean Chem. Soc. 2004, 25, 1833-1839.

43. Keller A; Nestizhskii. A. I.; Kolker. E.: Aebersold, R. Anal. Chem. 2002, 74. 5383-5392

44. Bae. T.-J.: Kim. M.-S.: Kim. J.-W. Kim. B.-W.: Choo. H. J: Lee. J.-W.: Kim. K.-B.: Lee. C.-S.: Kim. J.-H.: Chang. S. Y.: Kang. C.Y.: Lee. S.-W.: Ko. Y.-G. Proteonics 2004. 4. 3536-3548.

45. Görg. A.: Obermaier C: Boguth. G.: Harder, A: Scheibe. B.: Wildgruber R.: Weiss, W. Electrophoresis 2000. 21, 1037-1053.

46. Shevchenko. A.: Wilm, M: Vonm. 0: Mann. M. Anal. Chem. 1996. $68.850-858$.

47. Huang. M:: Zhu. X: Hao. Y: Payan. D. G.: Qu. K.: Li. M. Bioinformatics 2004. 20.3604-36,12

48. Tatusov, R. L.: Koonin. E. V.: Lipman. D. J. Science 1997, 278. $631-637$.

49. Südhof. T. C. Amm Rev. Netrosci. 2004, 27. 509-547

50. Satieddine. S.: Wenthold. R. J. Etw: J. Netwosci. 1999. 11. 803812

51. Luján. R.: Shigemoto. R.: López-Bendito. G. Neuroscience 2005.
$130.567-580$.

52. Reul. . . M.: Gesing. A.: Droste. S.: Stec. I. S.: Weber. A.: Bachmant1. C.: Bilang-Bleuel. A.: Holsboer. F.: Linthorst. A. C. Eur: J. Phamacol 2000, t05, 235-249.

53. Taylor, S. W.; Fahy, E.: Ghosh, S. S. Trends Biotechol 2003. 21. 82-88.

54. Doussau. F.: Augustine. G. T. Biochimie 20M0. 82. 353-363,

55. Chen. H.: Polo. S.: Di Fiore. P. P.: De Camilli. P. V. Proc. Natl. Acad Sci. LSA 2003. 100. 14908-14913.

56. Hoogenraad, C. C.: Wulf, P.: Schiefermeier. N.; Stepanova, T:; Galjart, N: Small. J. V: Grosveld, F.: de Zeeum, C. I: Akhmanova. A. EI $B O$ J. 2003, 22, 6004-6015.

57. Matanis. I.: Akhmanova. A.: Wulf. P.: Del Nery. E.: Weide. T.: Stepanova. T.: Galjart. N.: Grosveld. F.: Goud. B.: De Zeeuw. C. I.: Barnekow. A.: Hoogenraad. C. C. Nat. Cell Biol. 2002. 4. $986-$ 992

58. Short, B.: Preisinger. C.: Schaletzhy, J.: Kopajtich, R:- Barr, F. A Curr Biol. 2002. 12. 1792-1795.

59. Walch-Solimena. C.: Collins. R. N.: Norick. P. J. J. Cell Biol. 1997. 137. 1495-1509.

60. Brondyk. W. H.: McKiernan. C. I.: Fortner. K. A.: Stabila. P.: Holz. R. W.: Macara, I. G. Ifol. Cell Biol. 1995. 15, $1137-1143$.

61. Smalla, K. H.; Matthies, H.: Langnäse, K.: Shabir, S.: Böckers, T. M: Wyneken. U.: Staak, S.: Krug. M. Beeslev: P. W: Gundelfinger. E. D. Proc. Katl. Acad Sci. LSA 2000. 97. 43274332.

62. Li. X.: Gong. Y.: Wang. Y: Wu. S.: Cai. Y.: He. P.: Lu. Z.: Ying. W.: Zhang. Y.: Jiao, L.: He, H.: Zhang. Z.; He. F.: Zhao, X.; Qian. $\mathrm{X}$. Proteomics 2005.5 . 3423-3411.

63. Omenn. G. S.: States. D. J.: Adamski. M.: Blachwell, T. W. Menon. R.: Hermjakob. H.: Apweiler. R.: Haab. B. B.: Simpson. R. J.: Eddes. T. S.: Kapp. E. A.: Moritz. R. L.: Chan. D. W.: Rai. A. I.: Admon. A.: Aebersold. R.: Eng. J.: Hancock. W. S.: Hefta. S. A.; Mever. H.: Paik, Y. K.: Yoo, J. S.: Ping. P.: Pounds. J.; Adkins. J:; Qian, X.: Wang, R: Wasinger. V: Wu. C. Y; Zhao, X: Zeng. R.: Archakov, A.; Tsugita. A.: Beer. I.: Pandey, A.; Pisano. M.: Andrews. P.: Tammen. H.: Speicher. D. W.: Hanash. S. M. Proteontics 2005. 5. 3226-3245.

64. Aebersold. R.: Mant1. M. Nattre 2003. +22. 198-207.

65. Lim. H.; Eng. J; Yates. J. R. 3rd, Tollaksen, S. L; Giometti, C. S.; Holden, J. F.; Adams. M. W: Reich, C. I.: Olsen. G. J.: Hays. L. G. J. Am. Soc. Hass Spectrom 2003, 14,957-970.

66. Person. M. D.: Lo. H. H.: Towndrow. K. M.: Jia. Z.: Monks. I. J.: Laul. S. S. Chent. Res. Toxicol 2003. 16.757-767.

67. Li. K. W.: Hornshaw M. P.: Van Der Schors. R. C.: Watson. R.: Tate. S.: Casetta, B.: Jimenez, C. R.: Gouwenberg. Y.: Gundelfinger, E. D.; Smalla, K. H.: Smit. A. B. J. Biol. Chem 2004. 279. 987 1002 .

68. Witzmann. F. A.: Arnold. R. J.: Bai. F.: Hrncirova. P.: Kimpel. M. W.: Mechref. Y. S.: McBride. W. J:: Novotny. M. V: Pedrick. N. M.: Ringham. H. N.: Simon1. J. R. Proteonics 2005. 5. 2177. 2201 .

69. Schrimpt, S. P: Meskenaite, V:- Brunner. E; Rutishauser. D: Walther, P. Eng. J.: Aebersold. R.: Sonderegger. P. Proteonics 2005. 5. 2531-2541

70. Li. K.: Homshaw: M. P.: van1 Minten. T.: Snalla. K. H.: Gundelfinger. E. D.: Smit. A. B. J. Proteone Res. 2005. $4.725-733$ 